\title{
Saussurian Binary Opposition as the Narrative Structure of Williams' Summer and Smoke.
}

\author{
Anita Putri \& Paulus Sarwoto \\ Department of English Letters, Sanata Dharma University, Yogyakarta
}

\begin{abstract}
The Swiss linguist, Ferdinand de Saussure, is one of the forefathers of structuralism whose works have inspired and influenced many of current modern thinkers. Binary opposition is one of many of his thoughts. This notion came up from his theory explaining that in fact in humans attempt at deriving conceptual meanings, their minds work by distinguishing the differences between things. Thus, Saussure basically suggests the idea that humans first logical operation is by discerning things through their relationships; one of Saussure's basic relationships is binary opposition. For this reason, this study is conducted to prove this basic yet comprehensive theory as the narrative structure of Williams' Summer and Smoke. Tennessee Williams' Summer and Smoke (1948) is chosen since it is richly endowed with binary symbols and characters. Moreover, the course of the narrative is also structured in dichotomies.

The results of this study are: first, the binary symbols and characteristics found in the play reveal the dichotomies concerning the importance of soul/body, spirituality/sexuality, life/death, physical lust/divine love; second, the binary symbols and characters prove that the narrative structure of Summer and Smoke is constructed upon the binary oppositions as proven by the binary quests of soul and body and the binary role transformations between Alma and John as revealed by A.J. Greimas' three pairs of actantial model.
\end{abstract}

Key words: binary opposition, narrative structure, structuralism

\section{Introduction}

In learning a language, children are introduced to concepts and ideas through binary oppositions. As for examples, children cannot conceive the concept of dark when they do not know what light is, and the same goes for good and bad, beautiful and ugly, noisy and silent, etc. This explains the contemporary critics known as structuralists' belief that "things cannot be understood in isolation- they have to be seen in the context of the larger structures they are part of" (Barry, 2002: 39). This may be true since binary oppositions provide a systematic foundation which enables human to understand abstract and seemingly chaotic concepts or ideas more easily by putting the ideas into complementary pairs, such as body and soul, cause and effect, truth and lies, mundane and spiritual, living and existing, etc. Therefore, it can be concluded that binary opposition is one of many systems that governs human's mind to comprehend and derive meaning of concept and idea.

Binary opposition comes from Saussure's theory on structuralism. According to Saussure, binary opposition is

the means by which the units of language have value or meaning; each unit is defined in reciprocal determination with another term, as in binary code. It is not a contradictory relation but, a structural, complementary one (litencyc.com, 2005).

In other words, binary oppositions are pairs of related terms or concepts whose meanings are mutually exclusive. 
Binary opposition does not only serve in language when it comes to conceptual understanding. Many fields of studies use binary opposition as their tool in presenting their ideas. For example, there is famous concept like yin and yang in Chinese philosophy, angel and demon in religion like Christianity, to show concept of gender there is male and female in biology, etc. This shows that binary opposition is indeed indispensable and fundamental in every field of study including literature.

Speaking of literary study, there are many strategies which critiques may employ in order to have a critical and significant reading. Thus, the discovery of thematic binary opposition within a text may become one of the possible ways in grasping the intended meaning of the literary work or the readers' choice of interpretation. On the other hand, binary opposition may become author's way in presenting his/her works. Thus, binary oppositions can be considered very useful for both readers and authors. For the authors, binary oppositions help them establish, integrate, and highlight ideas and meanings within their works. For the readers, binary opposition enable them to have a big picture of a literary text as well as to get profound understanding of what is happening in a text.

This study focuses on these two objectives: firstly, to identify and analyze the symbols used in William's Summer and Smoke to reveal the characteristics of Alma and John; and, secondly, to explain in elaborative analysis of the way Saussurian binary opposition found in the symbols constructs the narrative structure of Williams' Summer and Smoke.

\section{Binary Opposition}

Since binary opposition is under the grand roof of structuralism, the understanding of structuralism is paramount. Structuralism, as Barry puts it, "is the belief that things cannot be understood in isolationthey have to be seen in the context of the larger structures they are part of" (2002:39). In other words, when one studies one literary work from the perspective of structuralism, he/she will aim at answering not what the meaning of that literary work is but how the meaning is produced. To do that, he/she will analyze the literary text by relating it to some mega-structures such as genre, history, or philosophy. Simply put, structuralists put great emphasis on how meanings are maintained and established and on the functions of the mega-structure in a literary work (Barry, 2002: 41).

G. Smith states that "binary opposition is the system by which, in language and thought, two theoretical opposites are strictly defined and set off against one another" (Smith, 1996:383). This concept comes from A Swiss linguist, Ferdinand de Saussure. He suggests that like language which governs human"s mind, binary opposition is the basic concept which influences human"s way of thinking. The reason behind this is explained by Selden in his book that "the essential point about this view of language is that underlying human use of language is a system, a pattern paired oppositions, binary oppositions (2005: 77).

In the phoneme level, for example, linguist comes to the paired system such as nasalized/non-nasalized, vocalic/non-vocalic, voiced/unvoiced, tense/lax. Therefore, binary oppositions, like Saussure suggests, are the means by which the units of language have value or meaning; each unit is defined in reciprocal determination with another term, as in binary code. It is not a contradictory relation but, a structural, complementary one (Fogarty, 2005).

Binary opposition, however, does not apply only in language use. A structuralist anthropologist, Claude Levi-Strauss, did his analysis on myth by using this linguistic model, which is binary opposition. He calls the unit of myths as "mythemes" which sound familiar as they are like phoneme and morpheme in linguistic study. He bisected the Oedipus myth to two underlying grounds i.e. first is over-valuing blood relation (Oedipus marries his mother, Jocasta) vs. undervaluing blood relation (Oedipus kills his father, Laius), second is between two views of the originality of human beings, i.e. born from earth vs. born from coitus (Selden, 2005: 80). 
By doing his study on myth, Strauss did not put interest in the myth's narrative sequence but in the structural pattern that provides the myth its meaning (Selden, 2005: $80)$. He points out that this linguistic model (binary opposition) will uncover the basic structure of human mind-the structure that governs the way human beings shapes all their institutions, artifacts, and forms of knowledge (Selden, 2005: 80).

Thus, in structuralists" point of view, the meaning of a literary work is not derived from the writer"s or reader"s experience, but from the underlying structure consisting of opposing ideas upon which literary work is built.

\section{The Theory of Narrative Structures}

The study of narrative structure is called narratology. It is a branch of structuralism. In closer look, narratology can be defined as "the study of how narratives make meaning" and "what the basic mechanisms and procedures are which are common to all acts of story-telling" (Barry, 2002: 223).

There are so many important figures majoring in this field of study. However, this study will use A. J Greimas" three basic patterns that he believes persist in all narrative. Greimas" theory is chosen since his theory emphasizes not the individual items but the structural relationship between them. This aspect of his theory is fundamentally derived from Saussure"s notion of binary opposition as the basic human conceptual mode. This is proven through his study, Semantique Structurale (1966), in which he succeeded in compressing Vladimir Propp'ss thirty-one "functions" of tales into only three pairs of binary oppositions that include six roles: (a) Subject/Object, Sender/Receiver, (c) Helper/Opponent.

The three pairs describe the three basic patterns which, as Greimas believes, are most likely to repeat in all narratives: (1) Desire, search, or aim (Subject/ object), (2) Communication (Sender/ receiver), (3) Auxiliary support or hindrance (Helper/ opponent) (Selden, 2005: 81).
Wanda Rulewicz explains Greimas" three basic concepts further in "A Grammar of Narrativity: Algirdas Julien Greimas". She explains that the subject is the entity who does the action, in this case who desires, who searches, who aims to do something while the object is the entity who becomes the target of desire, the target of the search, and the mark or end of the aim itself. Meanwhile, in her explanation on sender and receiver, she puts it as follows,

...the sender may be interpreted as the source of knowledge of the subject, and the receiver as the group of people or humanity in general which receives the message (Rulewicz, Sept 28, 2014).

Furthermore, she points out that

Sender and receiver may appear - and they usually do - as abstract notions, and they most often express the motivation of the subject to perform a certain action (Rulewicz, Sept 28, 2014).

In other words, sender can be understood as the one who instigates the action of the subject while the receiver is the party that benefits from the action of the subject.

Meanwhile, for the explanation for the helper and opponent, she states that "those who help the subject in his search are actanthelper, those who provide obstacles on his way - opponent" (Rulewicz, Sept 28, 2014). Thus, putting this six actants or roles, she uses the story of Holy Grail. Based on her findings on Holy Grail using Greimas theory, the subject appears as Knights of the Round Table; the object as the Grail, the sender as God, the receiver as Humanity, the helper as Saints and Angels, and finally the Devil and his acolytes constitute the opponent (Rulewicz, Sept 28, 2014).

To help see the relationship among the actantial roles better, the three pairs of binary actantial roles then will be organized into a schema, known as Actant Narrative Schema. The followings are the schema as depicted and thoroughly explained by Bronwen Martin and Felizitas Ringham (2006: 19): 
Vol. 16 No. 1 - April 2016

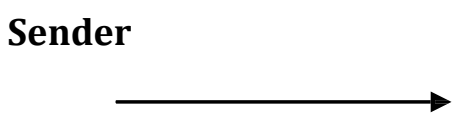

Helper

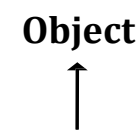

Subject

\section{Receiver}

Opponent
The schema illustrates firstly the relationship in communication, i.e. sender/receiver which according to Martin is "based on the desire for an object or on an obligation which the sender transmits to the receiver, inducing the later to pursue it" (2006:19). Hence, it can be concluded that the role of the sender is to put the receiver into action, thereby turning the receiver into a subject, the one that do the act of searching or wanting (Martin, 2006:19). This explanation as if answers the underlying reason for this arrangement claimed as the pertaining structure in love story.

Him $=\frac{\text { Subject and Receiver }}{\text { Her }}$

(Hawkes, 1977: 92).

\section{Symbols Representing Alma and John, and the Characteristics Revealed}

\section{Stone Angel}

The stone angel is the most prominent symbol of Summer and Smoke. Its prominence is clearly seen firstly, from its position in the stage. The author himself made special note ensuring its position in the stage:

Situated on this promontory are a fountain lifted and her hands held together to form a cup from which water flows, a public drinking fountain. The stone angel of the fountain should probably be elevated so that it appears in the background of the interior scene as a symbolic figure (Eternity) brooding over the course of the play (Williams, 1948:410).

From this quotation of the author's production notes, a conclusion can be drawn that the stone angel poses significant role in the play. With parallel postures and traits the stone angel and Alma share, it is inevitable that the stone angel acts as the symbol of Alma herself. In the prologue, Alma is depicted as a ten-year-old girl who "as a habit of holding her hands, one cupped under the other in a way similar to that of receiving the water at Holy Communion" (William, 1948: 411). Relating this depiction of Alma to the previous quoted author's note of the stone angel, reader can see the similar posture.

The stone angel also projects the same personality and principles as Alma. There are several reasons for this, firstly is because of the projection it has as an angel. Alma is also regarded as the angel of the play. This can be seen when Nellie reveals what John thinks of Alma, "He told me about how you came in the house that night like an angel of mercy (Williams, 1948: 454). Secondly is the role the stone angel and Alma play as comfort provider. The stone angel is always being where she is; showing her stagnancy in providing relief for those who wants to quench their thirst. The same goes for Alma since she becomes the one that provides John with serenity when John goes to her for comfort despite his impending marriage with Rosa Gonzales, saying -I will go in a minute, but first I want you to put your hands on my face.... [He crouches beside her]. Eternity and Miss Alma have such cool hands (Williams, 1948: 446).

Readers will know that in this scene John put Alma and the stone angel in parallelism to show that both provide comfort. Another parallelism is seen through Alma's name. It is said in the play's prologue that Alma is Spanish for soul (William, 1948: 413). The stone angel also has this idea of - soul. According to Chevalier, 
There are close links between stone and soul. Stones and humans display the twofold movement of rising and falling. Humans are born of God and return to God. Raw stones come down from heaven and when transmuted rises to the sky (Chevalier, 1996: 932).

From the explanation above about stone and soul, reader will see the resemblance between the stone angel and Alma from the fact that they both act as the bearer of the importance of soul over flesh thus spiritual over physical needs.

\section{Human Anatomy Chart}

The second most noticeable symbol is human anatomy chart. This is because the anatomy chart in the doctor's office dominates the scene almost as much as the figure of the stone angel does. Its first appearance is in the very last of scene 4 . In this scene, Alma goes to her next-door crush the Dr. Buchanan Jr. for some medicines that she cannot fall asleep. John then finds that nothing is wrong with Alma's body instead it is her being -lonesome\|t that troubles her. By this, John implies that what Alma needs is not medicine but love and thus, sex since at the moment John still believes in physical needs as the most important things in life. When the clock tells it is three, Alma goes back to her house but only after having been promised to have some riding with John. However, right after Alma leaves his house, John goes back to his previous postponed activity with Rosa Gonzales,

[John reaches above him and turns out the light. He crosses to Rosa by the anatomy chart and takes her roughly in his arms. The light lingers on the chart as the interior dims out] (Williams, 1948: 436).

The quotation above shows reader how the anatomy chart stands for John's debauchery tendency (his propensity to indulge his senses and physical pleasure). There is no real intention of John to be really with Alma as he can just take Rosa right after confessing his interest in Alma.
Hence, the anatomy chart in this play stands for John's contention in his childhood when he refuses the idea of being sent to college and following his father's footprint as a doctor saying -I'd rather be a devil, like they called me and go to South America on boat!\| (Williams, 1948: 413). From this statement of John, his inclination to the cavalier way of living is pretty obvious. He believes that it is better to live for the moment, indulging the senses while he can rather than to restraint himself for something that is not yet certain like "Eternity" Alma believes in.

Another significant appearance of the chart is in scene 8. In this scene, John gives Alma -an anatomy lecture:

JOHN, [with crazy grinning intensity] Now listen here to the anatomy lecture! This upper story's the brain, which is hungry for something called truth and doesn't get much but keeps on feeling hungry. This middle's the belly which is hungry for food. This part down here is the sex which is hungry for love because it is sometimes lonesome. I've fed all three, as much of all three as I could or as much as I wantedYou've fed none. (Williams, 1948: 448)

From the quotation above, it can be concluded that John gives little weight to spiritual matters and spends most of his time and energy fulfilling his physical wants and desires. Thus, the anatomy chart in this play also stands for John himself. He who regards worldly and physical pleasures above moral and spirituality gives no room for soul like the anatomy chart itself that is only a picture of human physical being and no soul in it.

\section{Telescope and Microscope}

The telescope and microscope symbolize the main characters. While Alma is represented by the telescope, John is by the microscope. It is in the first scene that they bring up the discussion about these optical devices. A telescope is an optical instrument that enables human to observe extraterrestrial things such as planet, comets, and star. It magnifies the distant objects for human to see. In contrast, microscope is an 
optical instrument that enables humans to examine terrestrial objects that are near but unseen-with-bare-eyes object.

Like telescope, Alma focuses her attention too much to the larger existence called "soul" compared to the "flesh". It can be seen through her puritan life that she follows strict moral rules and believes in the afterlife things like eternity. On the other hand, John weighs his credence on mortal things, or the body itself rather than thespirit. He shows no concern for norms prevailed in the society while take strong belief in "carpe diem" principle that life is only temporary and thus should be enjoyed as long as the body still permits.

Microscope also stands for John's psychological development. It is when Alma asks John about his study of bacteriology when microscope is brought up. Upon her curiosity, Alma continues prying after John on this topic and brings John to reveal what he sees when he uses microscope and he says "a universe, part anarchy, and part order!" (Williams, 1948: 418). Anarchy represents John's first state of mind in the play, which negligence, indolence, and indulgence are the prevailing qualities within him. These qualities are noted in Alma's lashing her disappointment on John:

ALMA. Most of us have no choice but to lead useless lives! But you have a gift for scientific research! You have a chance to serve humanity. Not just to go on enduring for the sake of endurance, but serve a noble, humanitarian cause, to relief human suffering. And what do you do about it? Everything that you can to alienate the confidence of nice people who love and respect your father. While he is devoting himself to the fever at Lyon, you drive your automobile at a reckless pace from one disorderly roadhouse to another! You say you see two things through the microscope, anarchy and order? Well, obviously order is not the thing that impressed you... (Williams, 1948: 423)
It is clear from the quotation that John indeed does not realize the importance of his job in the first half of the play. He still cannot grasp the meaning of responsibility, devotion or hard-work. All he knows is to indulge himself in all his glory, be the reckless man in town, and the negligent son.

However, this state of John's mind does not continue to be so. It evolves through his journey of self-realization and this is depicted in the second half of the play. It is after his father's death that he takes over his father's work. He devotes his time and energy for the sake of humanity, fighting against the epidemic in Lyon and stopping the fever. For the first time in the play, John is seen meddling with the microscope "John is seated at a white enameled table examining a slide through a microscope" (Williams, 1948: 455).

\section{Water Lily in Chinese Lagoon}

Water lily in Chinese lagoon represents Alma's other half. Water lily, as Chevalier puts it, has the equivalency with the lotus since both grow up from muddy water. As Chevalier puts it, water lily is the symbol of "the potential of the individual to realize the antithesis of his/her being" (Chevalier, 1996: 608-609). Unlike the other symbols, the binary opposition in water lily in Chinese lagoon is inherently represented in one entity. This can be seen when the dichotomies of purity and defilement, splendor and filth, beauty and dirt are drawn from this single entity. The conclusion of such dichotomies comes up by scrutinizing the nature of the flower. Growing in the muddy water, it is still pure and spotless. Hence, the beauty andfilthiness cannot be separated in attempt to define this flower since the dichotomies are parts of it. Viewed from this perspective, it indeed represents Alma's first and second selves; the first self is being the pure and upright minister's spinsterish daughter represented by the flower, water lily, while her second self is being a flirtatious seductress represented by the Chinese lagoon. In more thorough analyses, the water lily in Chinese lagoon also reflects the dichotomy of love and lust. This is drawn by the earlier dichotomy of pure soul and filthy body which in essence the way Alma loves 
and desires John. Her first half loves John with her soul while the second half projects lusts through her crave for the physical connection.

Thus, it is "water lily in Chinese lagoon" that signifies Alma's second self. In the first part of the play, John points out that Alma has a "doppelganger", a German word for "double", a second self. However, Alma does not know the existence of her second self until she meets John in their adulthood. The second half is actually the mirror image of the first's opposite. Hence, projecting Alma's first self which is self- conscious, restrained, and puritanical; her second self will be carefree, uninhibited, and cavalier. The first self of Alma also puts so much importance on the spiritual that leaves no room for her sensuality, which is the opposite of her second self who regards her sensuality above the moral or principles the first self upholds.

Water lily in Chinese lagoon is mentioned two times in the play. First in scene 4 when John gives her sleeping pills to let her have some sleep in her restless night. However, in this scene, Alma has not frilly realized her second self and just starts tofeel it, as she says "I'm beginning to feel almost like a water lily. A water lily on a Chinese lagoon" (Williams, 1948: 436). It is in the last scene of the play when she is about to enjoy the evening entertainment with the traveling salesman, does Alma fully realize upon the existence of her doppelganger, as she said "Yes, 1 feel like a water lily on a Chinese Lagoon "(Williams, 1948: 462).

\section{A Stone Pieta}

A stone pieta is Michael Angelo's sculpt of Virgin Mary with the dead Jesus Christ on her lap. John's attitude suggesting a stone pieta symbolizes John's leaving his body and goes for his soul. Such conclusion can be drawn from the background information about pieta. Pieta, according to Merriam Webster online dictionary, is "a representation of the Virgin Mary mourning over the dead body of Christ" (Webster, 2014). From this definition, it is important to note the fact that what is being mourned over is the act of Jesus leaving his physical being.
Jesus' being dead means His spirit is free from this word and its sufferings. Hence, John's action of pieta also suggests the same thing in essence i.e. to renounce his principles on physical pleasure- self-indulgence.

This particular scene can be found in the play when John, in his self- loathing and remorse, goes across to the Rectory for Alma's comfort. John says, "Eternity and Miss Alma have such cool hands. [He buries his face in her lap. The attitude suggests a stone pieta. Alma's eyes remain closed]" (Williams, 1948: 446). Here, John reveals about his being fed up with his selfindulgence. He refers to his previous summer, when he indulged all his senses senseless and should have been castrated. He regrets it that it leads him to find life meaningless.

It emphasizes the turning point in John's life when he at the end of the play becomes the one who regards the importance of spirituality and "soul" above the "body" or physical desires and needs. This gesture of John also symbolizes his repentance upon his summer's debauchery and larceny. Therefore, this particular symbol suggests the polarity of John's sin-virtue.

\section{Summer, Firework, Firecrackers, Fire}

The title of the play, Summer and Smoke, does represent the two main characters of this play; -summer\| here stands as passion. As "summer " is put on the entry along with "fire", it is more strategic to know what fire represents first to achieve the significance of "summer" in the play.

Chevalier states fire is strongly related to sexuality. He explains that "the sexual significance of fire is linked worldwide with the first technique of obtaining fire by up and down friction, the image of the sexual act" (Chevalier, 1996: 381). He also notes that -fire corresponds to south, the color Red, summer, and Heart. Fire also symbolizes the passions (especially those of love and hate) (Chevalier, 1996:379).

From Chevalier's exposition, a link can be drawn fromSummer and Smoke based on what he has said. First are firecrackers. It is in the first scene that these two object being 
shown. It is John who tosses down the firecrackers toward Alma's bench and later acts as a hero shooing the imaginative scoundrels. After this, Alma and John are spending the night of 4 of July talking on the bench. John notes Alma's unease which Alma blames it on the firecrackers. This discomfiture of Alma actually comes from within herself, i.e. her excitement and passion for John and not at all from the firecrackers. Also, along their heated argument upon Alma's being affected and John's being irresponsible, firework is displayed. This shows the "friction" and their passion for each other but are prevented to be together because of the tension and disagreement between them, one with soul but bodiless and one with body but soulless.

From the exposition above, it is clear that summer stands for the passion and sexuality of both characters. Their disagreement and differences bring them together and put them in contrast and thus shows how actually they crave for what the other has and to give what they have in return. This emphasizes summer as both character's passion for each other.

\section{Smoke}

Smoke, which also becomes one of the entities of the play's title, plays an important role in the play. It symbolizes Alma's soul leaving her body which marks her psychic regression. Chevalier discusses "smoke" in two different entries, first along with the entry of "fire" and second is on its own entry as "smoke". In the first entry, it is put as follows:

Fire which smokes and devours symbolizes an imagination inflamed, the subconscious, the hole in the ground, hell fire, the intellect in rebellion, in short all forms of psychic regression (Chevalier, 1996: 381)

While in the second entry, smoke is emphasized as "soul leaving the body" (Chevalier, 1996: 890).

The significance of smoke can be seen in scene 11, when Alma reveals her true feelings to John, she says
ALMA. One time I said -no// to something. You may remember the time, and all that demented howling from the cockfight? But now I have changed my mind, or the girl who sad -noll, she doesn't exist anymore, she died last summer-suffocated in smoke from something on fire inside her... (Williams, 1948: 456-457).

She reveals that she dies of smoke. It shows how she realizes that for all this time she has made a mistake puts imbalanced concerns between her sensuality and spirituality by ignoring her physical needs. Thus, smoke here marks the "soul leaving the body" and the death of old Alma. She has undergone rebirth through her realization over her sensuality. However, after her soul leaves the body, it means that Alma also leaves all her principles along with her soul. That means she no longer sticks to religious values she has always believed in and neither will she stay as a chaste woman as she no longer believes the importance of her soul.

Take a look in the very last seen of the play, when the travelling salesman asks Alma out to spend the night in Moon Lake Casino, and she knows well what is implied by such invitation, she, without showing her usual restraints, immediately accepts it. If seen from this point of view, it can be said that "smoke" here indeed stands for Alma's transformed self that she overlooks her usual common sense and morals. The transformation can be clearer viewed by comparing the Alma's now and then. Then, Alma abode to her principle about good sexual behavior i.e. no premarital sex. However, the current Alma as if forsakes all the morals that she can easily partake in the sexual invitation done by a mere passing stranger. If viewed from this perspective, "smoke"

\section{Binary Oppositions Revealed by the Symbols and Characters}

As all symbols have been identified and elaborated, they will be put into a table to reveal the characters' characteristics and dichotomies between them. 


\begin{tabular}{|c|c|c|}
\hline Symbols & The Revelation on Character's Characteristics & $\begin{array}{c}\text { Binary Opposition } \\
\text { Revealed }\end{array}$ \\
\hline $\begin{array}{l}\text { Stone Angel } \\
\text { vs. } \\
\text { Human Anatomy } \\
\text { Chart }\end{array}$ & $\begin{array}{l}\text { Alma: } \\
\text { Puritan (following strict moral rules and believing that pleasure is wrong), } \\
\text { spirituality above sexuality, dignified, angelic/kind, distant/lofty. } \\
\text { John: } \\
\text { carefree, uninhibited, Carpe Diem/Hedonist (believing that it's better to live } \\
\text { for the moment, indulging the sense), life above afterlife. }\end{array}$ & $\begin{array}{l}\text { Puritan - Hedonist } \\
\text { Spirituality - Sexuality } \\
\text { Afterlife - Life }\end{array}$ \\
\hline $\begin{array}{l}\text { Telescope } \\
\text { Vs, } \\
\text { Microscope }\end{array}$ & $\begin{array}{l}\text { Telescope: } \\
\text { It represents Alma's awareness and large-scaled aspiration, i.e.eternity. } \\
\text { The universe she sees is always related to God, the extraterrestrials thus } \\
\text { related to human spirits and the hereafter_-the divine and more abstract } \\
\text { notion. } \\
\text { Microscope: } \\
\text { What he sees is more physically related, thus it marks his focus on his } \\
\text { physical being rather than on the spirit. It represents the physical worldly } \\
\text { aspect of life. However, there is a dichotomy in what he sees through } \\
\text { microscope, i.e. anarchy and order. This dichotomy represents his old and } \\
\text { reformed self. The differences can be seen as follows: } \\
\text { In the beginning of the play: } \\
\text { Anarchy: negligent, reckless, lawlessness, self-indulgent. } \\
\text { In the end of the play: } \\
\text { Order : responsible, devoted, restrained, unselfish }\end{array}$ & $\begin{array}{l}\text { Soul - Body } \\
\text { Divine - Worldly } \\
\text { Abstract - Physical }\end{array}$ \\
\hline $\begin{array}{l}\text { Water Lily } \\
\text { vs. } \\
\text { Chinese Lagoon }\end{array}$ & $\begin{array}{l}\text { Alma's first and second half, the self-realization upon her duality. The first } \\
\text { self represented by the flower as the emblem of purity i.e. her spiritual self } \\
\text { while the second half represented by the muddy water, Chinese lagoon, as } \\
\text { the emblem of filthiness, i.e. her sexuality and physical need as human } \\
\text { being. Water lily in Chinese lagoon also reflects the dichotomy of love and } \\
\text { lust. This is drawn by the earlier dichotomy of pure soul and filthy body } \\
\text { which in essence the way Alma loves and desires John. Her first half loves } \\
\text { John with her soul while the second half projects lusts through her crave for } \\
\text { the physical connection. }\end{array}$ & $\begin{array}{l}\text { Purity - Filthiness } \\
\text { Beauty - Dirt } \\
\text { Love - Lust }\end{array}$ \\
\hline $\begin{array}{l}\text { Stone Pieta: } \\
\text { Dead Body } \\
\text { vs. } \\
\text { Living Soul }\end{array}$ & $\begin{array}{l}\text { John's self realization upon his soul, the manifestation of his embracing } \\
\text { "soul" and his repentance on his debauchery and decadence. John's action } \\
\text { of pieta marks the beginning of the reformed John, thus the birth of the } \\
\text { new John and the death of old John. }\end{array}$ & $\begin{array}{l}\text { Death - Birth } \\
\text { Body - Soul }\end{array}$ \\
\hline $\begin{array}{l}\text { Summer } \\
\text { vs. } \\
\text { Smoke }\end{array}$ & $\begin{array}{l}\text { Summer: } \\
\text { hn and Alma's passion for each other. It also acts as both characters" } \\
\text { "friction", the tension and disagreement between them. Thus, "summer" } \\
\text { represents life- the state of being alive as human. Hence, life indeed } \\
\text { needs the passion and tension to make it so. } \\
\text { Smoke: } \\
\text { Opposite to summer, smoke represents its antithesis, i.e. death. It marks } \\
\text { Alma's soul leaving her body. It means that "smoke" marks the death of } \\
\text { Alma's puritan side, her firstself }\end{array}$ & Life - Death \\
\hline
\end{tabular}




\section{Analysis on Binary Oppositions as the Narrative Structure of Summer and Smoke}

For this section, A.J. Greimas' theory of three pairs of actantial models is employed in attempt to reveal Saussurian concept, binary opposition, as the narrative structure of Williams' Summer and Smoke. Greimas theory is chosen since his theory is established from the underlying notion that binary oppositions is the bone of structural analysis of stories and thus, the common grammar which all stories springfrom (Hawkes, 1977: 89). Thus, it can be concluded that Greimas' theory of narrative structure has been derived from his predecessor's fundamental belief. In Hawkes' review on Greimas' theory, he says

In essence, his work attempts to describe narrative structure in terms of an established linguistic model derived from the Saussurian notion of an underlying langue or competence which generates a specific parole or performance, as well as from Saussure's and Jakobson's concept of the fundamental signifying role of binary opposition (Hawkes, 1977: 87-88).

Hence, using Greimas theory in discerning Summer and Smoke's narrative structure will prove the earlier hypothesis that Williams Summer and Smoke' narrative structure is constructed with Saussurian notion of binary opposition. The followings are the elaboration of the binary opposition as the play's narrative structure through three pairs of actantial models i.e. subject/object, sender/receiver, and helper/opponent as revealed by the earlier revelation upon the binary oppositions of the symbols and characters.

\section{Subject/Object (Desire, Search, or Aim)}

Subject is the entity who does the action, in this case who desires, who searches, who aims to do something while the object is the entity who becomes the target of desire, the target of the search, and the end of the aim itself (Rulewicz, Sept 28, 2014). In Summer and Smoke the roles of subject and object are attributed to the main characters Alma and John. Both the characters are the subject and the object of this play since not only both characters pursue to their second self, but also they represent the missing second half of the other character. All the symbols found in this thesis show this subject-object opposition. The twofollowing illustrations will show how Alma is the subject and John is the object and vice versa in the second illustration based on the revelation of the symbols.

\section{a. Subject $=$ John \\ Object $=$ Alma}

Firstly, the water lily in Chinese lagoon representing Alma's second half shows Alma as the subject and John as the object as Alma searches for her other half which is represented by John. She desires what is represented by John, i.e. sexuality and hedonism. As the human anatomy reveals, John is carefree, passionate, and full of vigor. The uptight and morally-strict Alma sees the carefree John with interest ever since their childhood. The innocent interest then grows to be more sexual by the time they reach adulthood. As the symbol, "summer" indicates, there is a thick sexual tension between Alma and John which comes from Alma's passion for John. Therefore, in this case, John becomes the object since he is the target of Alma's desire. Alma's pursuit of her second half represented by the water lily surely correlates to John's devotion to pleasure which represented by the human anatomy chart. This pursuit of Alma's doppelganger is not fruitless as she at the end of the play embraces her sexuality and is able to express it like the symbol "smoke" shows. "Smoke" standing for death-rebirth dichotomy of Alma's spiritual and sexuality marks the end result of Alma's search of her second self represented by John. For this reason, Alma becomes the subject who searches for her doppelganger, who aims to embrace her sexuality, who desires the man acting as her second half and John becomesthe object since he is the target of Alma's desire and the one that represents Alma's second half. 


\section{b. Subject $=$ Alma \\ Object $=$ John}

Secondly, John becomes the subject while Alma is the object. This can be seen on how John also desires Alma but in a different motive. He desires her but not in physical way as he is afraid of her soul. As the stone angel reveals, Alma is unreachable since she is too refined, dignified, and pious as if she comes from the higher realm where the angels dwell. John is aware of Alma's sublime characteristics and upbringing that he does not think himself worthy of her. This is clearly depicted in his revelation about his feeling unworthy that he cannot touch her,

JOHN. I'm more afraid of your soul that you're afraid of my body. You'd have been as safe as the angel of the fountain-because 1 wouldn't feel decent enough to touch you (Williams, 1948:, 449).

Consequently, John's implicit notion about "the angel of the fountain" as being "safe" and thus pure and untouchable reveals how John regards Alma the same as one of the angel, pure, safe, and untouchable and thus sacred. He considers her as light in darkness and water for thirst that she comforts him in his remorse upon his past debauchery just like what the symbol stone pieta reveals. This means that actually John is craving for the comfort that is provided by her and the aspect of religious and spirituality that are represented by Alma. This can be proventhrough the symbols stone pieta and the microscope since both these symbols mark John's realization upon his spiritual side. After realizing the importance of spirituality, John then turns into a different person. He devotes himself to his profession as a doctor and becomes more responsible as he is going to commits to a marriage which previously has been unthinkable. Like what the symbol microscope indicates, he then gives up his "anarchy", the hedonistic negligent lawless way of life to hold onto the "order", the responsible devoted self. For this reason, John becomes the subject that searches for the spiritual comfort and Alma becomes the object since she represents the spirituality and "order" that John aims for.

Alma and John's subject and object roles are strengthened by the idea that each John and Alma stands for two different selves; John for the physical while Alma for the spiritual self. This theme of divided self is the one that constructs the play asits narratives structure as it reveals the journey of two characters in their self- realization.

\section{Sender/Receiver (Communication)}

Sender can be understood as the one who instigates the action of the subject while the receiver is the party that benefits from the action of the subject (Rulewicz, Sept 28, 2014). It should be noted that senderreceiver roles "may appear - and they usually do - as abstract notions, and they most often express the motivation of the subject to perform a certain action" (Rulewicz, Sept 28, 2014). It is also important to highlight the correspondence between sender-receiver and subject-object binary oppositions. Based on the previous discussion on subject- object actants, the main characters, i.e. Alma and John, are both the subject and object ofSummer and Smoke. Accordingly, both Alma and John become the sender and receiver of this play. As Greimas indicates, -in a banal love story, the following structure pertains:

$$
\text { Him }=\frac{\text { Subject and Receiver }}{\text { Her }}
$$

(Hawkes, 1977: 92).

According to Greimas, the receiver is the one that benefits from the subject's action. Hence, in the love story, the one that will gain the benefit of the subject's search of true love is none other than the subject itself since he/she is the one that gain something from his/her search. However, inSummer and Smoke, the search is confined to more specific aspect other than love but the characters other half/self. Thus, the subject is the receiver, the one that profits from his/her search of self. Accordingly, the object, which is described as the one that instigates the actions of the subject, stands as the sender 
since it is the one that stirs up the desire to find their other missing half.

In the idea of communication, the act of transferring belief does happen successfully since both characters end in embracing the others' belief and finding their missing self. However, this results in their inability to be together because the differences between them are not bridged but prevail. This unfortunate turn of event is caused by the simultaneous change in both of Alma and John's point of view in life.

\section{a. Alma $=$ Subject and Receiver \\ John Object and Sender}

Acting as the subject, Alma searches for her second half, i.e. her sexuality which is represented by John. She desires John and at the same time doppelganger (her second self) which is repressed. By this logic, John becomes the sender since he instigates Alma's pursuit of self-identity. The symbol human anatomy chart represents this other half that Alma has been missing out, i.e. the flesh as the vessel of the soul. The process of communication happens when John gives Alma the "anatomy lecture".

JOHN, [with crazy, grinning intensity] Now listen here to the anatomy lecture! This upper story's the brain, which is hungry for something called truth and doesn't get much but keeps on feeling hungry. This middle's the belly which is hungry for food. This part down here is the sex which is hungry for love because it is sometimes lonesome. I've fed all three, as much of all three as I could or as much as I wanted-You've fed none. (Williams, 1948: 448)

However, in the second part of the play, Alma finds that John has changed his point of view into her old way of thinking when she herself has abandoned it for John's. Hence, Alma becomes the receiver of John's newfound spirituality. John now becomes the sender of propriety and the importance of soul over body andAlma becomes the receiver end of this belief. This particular change is marked by thechange of characters in both Alma and John. John, at the end of the play, has becomethose who regard spiritual above physical pleasure. Thus, the anatomy chart, theemblem of body, turns to be the reminder of the supremacy of soul as the generator ofthe machine, one that makes the body function. This is clearly depicted in scene 11 ,when John sincerely admits he loses the argument over the anatomy chart. $\mathrm{He}$ realizes now that the soul does exist and becomes the 'machines' whole reason for being" (Williams, 1948:, 457). Thus, John's transformed self puts Alma in the positionto receive the message, i.e. the importance of morality, spirituality, and propriety.

\section{b. John = Subject and Receiver \\ Alma Object and Sender}

In this part, the discussion will revolve around John as the subject and thus the receiver of the play and Alma as the sender. As the stone pieta reveals, John actually desires Alma. He craves for the spiritual comfort Alma provides. In the beginning of the play, Alma goes into confrontation with John upon the importance of spirituality and responsibility. Then, she is the sender of the superiority of the soul over the body, the spirituality over worldly pleasures. The receiver is John who does not believe in the soul and is therefore recklessly wallowing in his self-indulgence. John's different point of view regarding priority in life sends Alma into lecturing him upon his decadent lifestyle. This is clearly depicted in the first half of the play, scene 1 until scene 6 . In scene 1, Alma reprimands John's recklessness that instead of devoting himself like his father to humanity as a reputable doctor, he pleases himself with self- partying and self"desecration" as Alma puts it. This particular scene shows how Alma regards spirituality higher than worldly pleasures. The passionfriction binary opposition revealed by summer can also be seen in scene 6. Alma reiterates her ideology on the superiority of spirituality that she refuses to enter the casino, which represents the opposite of spirituality. That is how the disagreement happens between John and Alma since Alma 
refuses John the -connubial felicityll that John implies to her. She shows her repugnance to John promiscuity and thus tries to defend herself by highlighting the importance of spiritual love that John is missing out.

After the role reversal takes place, however, the transformation does occur in Alma's belief. She, then, no longer becomes the sender of the importance ofspirituality and morality but turns to be the sender of John's previous principle, i.e. body over soul. The role-reversal can be seen through Alma's impulsiveact of kissing John, [She suddenly leans toward him and presses her moth to his] (Williams, 1948: 456) and her revelation of the death of her first self:

ALMA. ... One time I said -noll to something. You may remember the time, and all that demented howling from the cock-fight? But now I have changed my mind, or the girl who sad -noll, she doesn't exist anymore, she died last summer - suffocated in smoke from something on fire inside her. No she doesn't live now, but she left me the ring-You see? (William, 1948: 456457).

This is when the symbol -smoke\|l highlights the transformation of Alma that it stands for Alma's soul leaving her body which marks her newfound hedonistic self. Therefore, Alma now takes over John's role in the beginning of the play by being the sender of the importance of the flesh as the vessel of the soul as she relays her dialogue with her old self to John:

ALMA. Remember I died empty handed, and so make sure that your hands have something in them!" [She drops her gloves. She clasps his head again in her hands.] I said. "But what about pride?". She said, "Forget about pride whenever it stands between you and what you must have" (Williams, 1948: 457)

Alma also shows her desperation on their perpetual disagreement on their principles. Her desperation is shown through her outburst of emotion as she puts it:
ALMA......... The tables have turned, yes, the table has turned with avengeance! You've come around to my old way of thinking and I to yours like two people exchanging a call on each other at the same time, and each one finding the other one gone out, the door locked against him and no one answer the bell! [She laughs] I came here to tell you that being a gentleman does notseem so important to me anymore, but you're yelling me I've got to remain a lady.[She laughs rather violently] ... (Williams, 1948:, 1948: 458-459).

The never changing relationship despite the role reversal is caused by both Alma and John success in influencing one another to develop their characteristics to the others' direction. This means that Alma turns to be worldlier in her way of thinking and John starts to embrace Alma's belief which is spirituality-ridden. Unfortunately, they both do that in simultaneous time which makes them walk their separate ways again. That is how the communication between them never culminates in agreement that these two characters are unable to entwine their belief and principles.

\section{Helper/Opponent \\ (Auxiliary Support or Hindrance)}

The helper is those who help the subject in his search while those who provide obstacles on his way are regarded as the opponent (Rulewicz, Sept 28, 2014). In Summer and Smoke, It is clear from the characters' character development that the two characters, Alma and John, act as both helper and opponent to each other. The followings will illustrate how Alma and John become not only the opponent but also the helper to each other:

\section{a. Alma = Opponent \\ John Helper}

In the quest of her missing self, Alma is exposed to John whose personality and belief which is contrary to hers. The differences between them are so palpably crafted by Williams in the very beginning of 
the play through the use of the symbol the stone angel. In the prologue introducing Alma and John in their childhood, the stone angel is employed to show Alma's stance, i.e. the importance of afterlife instead of the physical life-the spirituality over the worldly aspect. Hence, it is crystal clear that in the beginning Alma stands for the spirituality.

However, when she reaches adulthood, she starts to reveal her other need other than spirituality. The symbol water lily in Chinese lagoon seems to provide the explanation for Alma's altercation - the pure spiritual lady who owns sexual desire. Thus, in her struggle in finding her second self, the carefree sexual young lady, she is hindered by her own self, the rigid spiritual spinster. Being a priest daughter indeed influences her upbringing which is spiritual-ridden but it also becomes the reason why Alma vigorously denies her sexual being dwelling inside her since she has been living up to everyone's expectation of her to be the priest's well-behaved daughter. For this reason, Alma acts as the opponent of herself in her quest of her second self.

In contrast, John plays a role as the helper in Alma's quest of her sexual being. Different from Alma, John stands for the physical, worldly aspect of life. Through the symbol human anatomy chart, it is revealed that his concepts of life is to fulfill three kinds of needs; knowledge for brain, food for belly, love for sex (Williams, 1946: 448-449). All the needs are physical and unrelated to the divine. That is how his personality is so different from Alma's. He is carefree, reckless, and self-indulgent; directly in contrast with Alma who is prudish, responsible and devout. Acting as her antithesis, John also plays the role as helper since he is the one that introduces and shows Alma how to let her second self come to the surface. In contrast, John plays a role as the helper in Alma's quest of her sexual being. Different from Alma, John stands for the physical, worldly aspect of life. Through the symbol human anatomy chart, it is revealed that his concepts of life is to fulfill three kinds of needs; knowledge for brain, food for belly, love for sex (Williams, 1946: 448-449). All the needs are physical and unrelated to the divine. That is how his personality is so different from Alma's. He is carefree, reckless, and self-indulgent; directly in contrast with Alma who is prudish, responsible and devout. Acting as her antithesis, John also plays the role as helper since he is the one that introduces and shows Alma how to let her second self come to the surface.

Another symbol showing John as Alma's helper is the symbols smoke. The symbol smoke reveals another binary opposition, i.e. death and birth. The second binary opposition of the symbol smoke sees Alma's character development into brighter light. It shows progress rather that regression since it means that Alma succeeds in releasing her depressed life and she becomes more true to herself as she no longer denies her sexuality. By putting it through this point of view, the symbolsmoke reveals how John helps Alma in finding her true self. This is because the smoke is the result of the repressed passion Alma feels for John. Thus, indirectly, John is the one that triggers Alma's character fulfillment.

\section{b. Alma $=\frac{\text { Helper }}{\text { John }}$}

The recurrent pattern of the first self as the opponent of the second self occurs in John's pursuit of self-realization. In the very beginning of the play, Williams has put John as Alma's opposite. The quest of his second self is manifested through John's pursuit of Alma. Serving as the spiritual self, Alma indeed shows John different point of view in life. However, John has mistaken his interest in Alma, i.e. the spiritual bearer, for his usual sexual pursuit. This misjudgment on his part upon his intention is derived from his own deep dwelling upon physical indulgent.

John is depicted as the rebellious young boy whose aspiration is to be a devil, like what everyone has expected from him and to "go to South America on a boat" (Williams, 1948:413). As the symbol human anatomy chart also reveals, John's mindset upon life revolves around physical fulfillments. His first self has no regard for spirituality; neither moral nor social conventions can curb John's hedonistic inclination. He spends his summer 
with overtly sexual promiscuity and irresponsible behaviors such as drinking and reckless driving. He has no room for morality and thus acts impulsively without forethought. In his self-remorse then it is revealed thathe actually feels hollow inside. He is hugely indebted in gambling that he has to marry the Casino's owner's daughter, Rosa Gonzales resulted in two of them planning to go to South America. Upon realizing this, he, instead of feeling content that his aspiration is about to be fulfilled, feels remorseful that he despises his pass debauchery. For that reason, the one that hinders John's struggle for spiritual self is his hedonistic self.

As for the role of helper in the quest of John's self-realization, it is none other than Alma-the embodiment of spirituality in the play. In his struggle upon finding his spiritual level of being, the higher consciousness, John is starkly juxtaposed with the ever divine Alma. She helps John to find his spiritual self by providing spiritual comfort in time of his self-remorse. Alma, who is depicted as the angel of the play, indeed acts upon the image of an angel, the all benevolent messenger of God. She provides John the spiritual comfort in time of his self- remorse. As the symbol stone pieta reveals, it is Alma to whom John goes for relieving his sorrow upon his summer debauchery. She is the one that provide spiritual solace for John. Her effect upon John's life can be seen through the conversation between Alma and Nelly after Alma's long reclusion:

ALMA. You mean you-spoke well of me? NELLIE. -Well of"! We raved, simply raved! Oh, he told me the influence you had on him!

ALMA. Influence?

NELLIE. He told me about the wonderful talks he'd had with you last summer when he was so mixed up and how you inspired him and you more than anyone else was responsible for his pulling himself together, after his father was killed, and he told me about... [Alma rises stiffly from the bench.] Where are you going, Miss Alma?

ALMA. To drink at the fountain.
NELLIE. He told me about how you came in the house that night like an angel of mercy! (Williams, 1948: 454)

It is also Alma that points out the existence of the spirit, as he puts it "the machines, the whole reason for being" (Williams, 1948: 457). Alma's propagation of the importance of spirituality in life leads to not only John's realizing his spiritual being but also the -order' in his life. Like what the symbol microscope reveals, previously John's life is "anarchic"-without controlling rules of morality or principles to pertain order. Even though he graduates with doctoral degree in bacteriology, he never has intention let alone acts upon using his knowledge to help mankind relieve the sufferings caused by diseases. He is too self-absorbed that his aspiration rests in fulfilling his physical pleasures. However, in the end of the play, John succeeds in pulling himself together, i.e. recovering control of his life. He starts contributing to medical world by continuing his father's work to fight off the fever epidemic in Lyon. From there, he starts building his reputation as the responsible young doctor. He no longer dwells upon his remorse upon the past summer when he mindlessly ignoring his soul. All this reformation is attributed to Alma's influence. For this reason, Alma is the helper in John's quest of soul.

\section{Conclusion}

The symbols discussed above, along with their revelation upon the two main characters' characteristics, reveal that the narrative structure of Williams' Summer and Smoke is constructed upon Saussurian binary opposition. The results are shown through Greimas' three basic binary oppositions, i.e. subject/object, sender, receiver, helper/opponent.

The results are shown through the following table:

1. Stone Angel vs. Human Anatomy Chart = Spirituality vs. Physical

2. Alma's duality $\rightarrow$ Alma $^{1}=$ Water Lily vs. Alma $^{2}=$ Chinese Lagoon 
3. John's duality $\rightarrow \mathrm{John}^{1}=$ "Anarchy" vs. John ${ }^{2}=$ "Order"

4. Summer vs. Smoke = Physical Lust/Passion vs. Divine Love/ Soul

5. Alma's reformation $=$ Smoke $\rightarrow$ Death of soul to the. Birth of body

6. John's reformation $=$ Stone Pieta $\rightarrow$ Death of body to the Birth of Soul

\begin{tabular}{|c|c|c|}
\hline \multicolumn{3}{|c|}{ Alma's Quest of Her Body } \\
\hline Sender & Object & Receiver \\
\hline Summer & John ${ }^{1}$ & Alma $^{2} \rightarrow$ Smoke \\
\hline Helper & Subject & Opponent \\
\hline $\begin{array}{c}\text { Human } \\
\text { Anatomy Chart }\end{array}$ & Alma ${ }^{1}$ & Stone Angel \\
\hline \multicolumn{3}{|c|}{ John's Quest of His Soul } \\
\hline Sender & Object & Receiver \\
\hline Smoke & Almal ${ }^{1}$ & John ${ }^{2} \rightarrow$ Stone Pieta \\
\hline Helper & Subject & Opponent \\
\hline Stone Angel & John ${ }^{1}$ & Human Anatomy Chart \\
\hline
\end{tabular}

According to the results, firstly, the binary symbols and characteristics found in the play reveal the dichotomies concerning the importance of soul/body, spirituality/ sexuality, life/death, physical lust/divine love; secondly, the binary symbols and characters prove that Williams' Summer and Smoke's narrative structure is constructed upon the binary oppositions as proven by the binary quests of soul and body and the binary role transformations between Alma and John as revealed by A.J. Greimas' three pairs of actantial model.

As structuralism indicates, instead of focusing on the actual meaning of literary works, structuralists aim at finding on how meanings are maintained and established and on the functions of the mega-structure in a literary work. Accordingly, the results show how binary oppositions act as the grammar or in this case the langue of the parole Williams' Summer and Smoke. The themes of the dramatic text such as the quest of self- knowledge, the pursuit of higher consciousness, the struggle between spirit and flesh are carried through the dichotomies of the symbols and the main characters.

\section{References}

Abrams, M.H. A Glossary of Literary Terms: Seventh Edition. New York: Heinle\&Heinle, 1999.

Arp, Thomas R. and Greg Johnson. Perrine's Literature: Structure, Sound, and Sense. Boston: Heinle\&Heinle, 2006.

Augustten, Ayunda. “Alma Winemiller's Psychological Conflict as Seen in Tennessee Williams' Summer and Smoke". Thesis. Yogyakarta: Sanata Dharma University, 2004.

Barranger, Milly S. Theater, A Way of Seeing. Fourth Edition. New York: Wadsworth, 1994.

Barry, Peter. Beginning Theory: An Introduction to Literary and Cultural Theory. Second Edition. New York: Manchester University Press, 2002.

Chevalier, Jean and Alain Gheerbrant. Translated by John Buchanan-Brown. The Penguin Dictionary of Symbols. London: Penguin Group, 1996.

Chun An, Guo. "Binary Oppositions in Paradise Lost: A Structuralist Reading Strategy". Kaohsiung Journal Ninth. Web. $<$ lib.kshs.kh.edu.tw/lib/journals/journal s.../p59.pdf> September 26, 2014.

Dewi, Utari. "A Study of Character Development of Alma Winemiller and John Buchanan in William's Summer and Smoke". Thesis. Yogyakarta: Sanata Dharma University, 2000. 
Fogarty,S, "The literary Encyclopedia”. 2005. Web. <http://www.litencyc.com/php/ stopics.php?pec=true\&UID=122) April 6, 2014.

Gill, Richard. Mastering English Literature: Second Edition. New York: Palgrave Macmillan Ltd, 1995.

Hawkes, Terence. Structuralism and Semiotics. London: Methuen \& Company Limited, 1977.

Martin, Bronwen and Felizitas Ringham. Key Terms in Semiotics. London: MPG Books Ltd, 2006

Pryor, Jerome J. "The Discovery of Dionysus inTennessee Williams'Summer and Smoke". Web. <http://brpryor.com/ Papers/Summer_and_Smoke96.htm> September 26, 2014.

Reaske, Christopher Russell. How to Analyze Drama. New York: Monarch Press, 1966.

Rulewicz, Wanda. "A Grammar of Narrativity: Algirdas Julien Greimas". Web.< http://www.arts.gla.ac.uk/ STELLA/COMET/glasgrev/issue3/rudz.h tm>. September 28, 2014.

Selden, Raman, Peter Widowson, and Peter Brooker. A Reader's Guide to Contemporary Literary Theory. Fifth edition. Edinburgh: Pearson Education Limited, 2005. Web.

<http://pearson.vrvbookshop.com/book /a-readers- guide-contemporaryliterary-theory-raman-selden/ 9788177589979> September 15, 2014.

Smith, G. "Binary opposition and sexual power in Paradise Lost". Midwest Quarterly. Vol. 27 No. 4. P. 383. 1996.

Webster, Merriam. Merriam-Webster Online, Merriam-Webster Incorporated. 2014. Web. <http://www.merriamwebster.com/ dictionary/pieta>. September 08, 2014.
Williams, Tennessee. Summer and Smoke. 1948 in Modern American Drama. ed. Harold Bloom. Ed. Philadelphia: Chelsea House Publishers, 2005. pp. 409-462. 